\title{
Coastal Erosion and Management in the People's Republic of China
}

\section{Shilong Luo ${ }^{1,2 *}$}

${ }^{1}$ College of Marine Geosciences, Ocean University of China, Qingdao 266100, China

${ }^{2}$ Third Institute of Oceanography, State Oceanic Administration, Xiamen 361005, China

Coastal erosion is concerned all around the world, for which is a problem at many coastal sites exacerbated by human activities, and its adaptive management through reasonable mitigation measures is also in the ascendant.

China has a coastline of $32,000 \mathrm{~km}$, third of which is occupied by sandy coast. According to the latest report of the State Oceanic Administration (SOA, PRC), $3,255 \mathrm{~km}$ soft coast is suffering from severe coastal erosion, $76 \%$ of which is sandy coast, the rest contributed by muddy coast. Coastal erosion results in heavy land loss and aggravates financial burden, which is unacceptable. Coastal erosion management of China, aiming at facilitating the sustainable relationship between socioeconomic development and protection of coastal environment, is a systematic process of using scientific technology, administrative and economic policy to realize a socialized, scientific and informative coastal erosion management system in order to minimize the adverse impacts of coastal erosion hazard.

Since 1990's, the implementation of coastal erosion management in China has began, the theory and practice of which were depicted by lots of literatures. The causes and effects of coastal erosion, coastal erosion assessment and management, natural disaster risk assessment, geological characteristics of coastal disaster and coastal erosion mitigation measures were all involved in these literatures. The Chinese Offshore Investigation and Assessment (COIA) project launched in 2007 has accomplished the assessment of coastal erosion hazard and provided mitigation measures of hard and soft structures for controlling coastal erosion. The project of Sandy Coast Nourishment and Restoration in China (SCNR) will be finished in 2012, its main objective is to develop and test beach nourishment as a measure for reducing erosion along the sandy coast of China, based on the available scientific knowledge and practical experiences. These works did provide large amounts of fundamental data and successful experience, which guide the managers and researchers to find a more harmonious process for risk reduction of coastal erosion.

Presently, the available mitigation measures for coastal erosion in China are threefold: 1) managed realignment, the most preferred measure, containing construction of SBL (setback line), transformation of LUCC (land use/cover change) and establishment of the coastal natural reserves; 2) advance the line, building new defenses on the seaward side of the original defenses such as reclamation; 3 ) hold the line, the most popular measure, including soft nourishment and hard engineered structures. Two thirds of Chinese mainland coastline is protected by seawall; soft nourished coastline in China amounts to $10,400 \mathrm{~m}$, nourished volume more than 2 million $\mathrm{m}^{3}$ by the end of 2009 and 20 mangrove or coral reef natural reserves has been established along the subtropical coastal areas. These mitigation measures hold the existing shoreline and keep the safety of habitants and constructions from destroying.

The successful implementation of coastal erosion management in China does not imply that all problems have been solved. Issues such as climate change, development in societal pressure on the coast and increasing knowledge on coastal system, constantly challenge the existing approaches. I hope to share the coastal erosion and management status in China with people interested and welcome advice and cooperation from researchers and managers.
*Corresponding author: Shilong Luo, College of Marine Geosciences, Ocean University of China, Qingdao 266100, China, Tel: +86 13950118683; E-mail: Is104025@yeah.net

Received August 20, 2013; Accepted August 27, 2013; Published September 02, 2013

Citation: Luo S (2013) Coastal Erosion and Management in the People's Republic of China. J Coast Dev 16: e101. doi: 10.4172/1410-5217.1000e101

Copyright: () 2013 Luo S. This is an open-access article distributed under the terms of the Creative Commons Attribution License, which permits unrestricted use, distribution, and reproduction in any medium, provided the original author and source are credited. 